\title{
Temporal Evolution of Neointimal Proliferation After Implantation of Two Types of Drug-eluting Stents with Biodegradable Polymers in a Porcine Model: Qualitative Assessment by Sequential Optical Coherence Tomography
}

\author{
Micheli Zanotti Galon', Celso Kiyochi Takimura², Juliana Carvalho³, Márcio José Figueira Chaves, \\ Silvia Lacchini ${ }^{5}$, Vera Demarchi Aiello ${ }^{6}$, Paulo Sampaio Gutierrez ${ }^{7}$, \\ Francisco Rafael Martins Laurindo ${ }^{8}$, Pedro Alves Lemos Neto $^{9}$
}

\begin{abstract}
Background: Based on the hypothesis that the neointima found in drug-eluting stents (DES) with biodegradable polymers at 28 days is not a definitive neointima and that optical coherence tomography (OCT) is an effective method for sequential neointimal evaluation, we aim, in this experimental study, to compare OCT findings at 28 and 90 days, in two different DES with biodegradable polymers: the sirolimus-eluting stent (Inspiron ${ }^{\circledR}$, Scitech) and the biolimus A9-eluting stent (Biomatrix ${ }^{\circledR}$, Biosensors International). Methods: Overall, 6 non-atherosclerotic pigs were submitted to the implantation of 6 Inspiron $^{\oplus}$ stents and 6 Biomatrix ${ }^{\circledast}$ stents. Each pig received both stent types, one in each coronary artery (left anterior descending artery and circumflex artery) and after 28 and 90 days qualitative in-stent OCT analyses were performed at 1-millimeter intervals. Results: Qualitative assessment was performed in-stent pairing millimeter by millimeter. Heterogeneous neointimal tissue was evidenced in $39 \%$ at 28 days and in $0 \%$ at 90 days, the presence of intraluminal tissue in $18 \%$ at 28 days and in $0 \%$ at 90 days, luminal irregularity in $62 \%$ at 28 days and in $2 \%$ at 90 days $(P<0.005)$. There was no difference between groups regarding the quality of the neointima over time $(P>0.05)$. Conclusions: The OCT findings corroborate the hypothesis that the neointima found in DES with biode-
\end{abstract}

\section{RESUMO}

Evolução Temporal da Proliferação Neointimal após Implante de Dois Tipos de Stent Farmacológico com Polímeros Biodegradáveis em Modelo Porcino: Avaliação Qualitativa por Tomografia de Coerência Óptica Sequencial

Introdução: Baseados na hipótese de que a neoíntima encontrada em stents farmacológicos (SFs) com polímeros biodegradáveis aos 28 dias não é a neoíntima definitiva e de que a tomogra fia de coerência óptica (TCO) é um método eficaz para a avaliação sequencial da neoíntima, objetivamos, neste estudo experimental, comparar os achados da TCO aos 28 dias e aos 90 dias em dois tipos de SF com polímeros biodegradáveis: o stent liberador de sirolimus (Inspiron ${ }^{\circledR}$, Scitech) e o stent liberador de biolimus A9 (Biomatrix ${ }^{\circledR}$, Biosensors International). Métodos: No total, 6 porcos não-ateroscleróticos foram submetidos a implante de 6 stents Inspiron ${ }^{\circledast}$ e de 6 stents Biomatrix ${ }^{\oplus}$. Cada porco recebeu os dois tipos de stent, um em cada artéria coronária (descendente anterior e circunflexa) e após 28 dias e 90 dias foram rea lizadas avaliações qualitativas intrastent a cada milímetro com TCO. Resultados: A avaliação qualitativa, feita por pareamento milímetro a milímetro intrastent, evidenciou neoíntima heterogênea em 39\% aos 28 dias e em

\footnotetext{
Master. Interventionist Cardiologist Physician-researcher at Instituto do Coração do Hospital das Clínicas da Faculdade de Medicina da Universidade de São Paulo. São Paulo, SP, Brazil.

${ }^{2}$ Doctor. Physician-researcher at Instituto do Coração do Hospital das Clínicas da Faculdade de Medicina da Universidade de São Paulo. São Paulo, SP, Brazil.

${ }^{3}$ Biomedical physician at Instituto do Coração do Hospital das Clínicas da Faculdade de Medicina da Universidade de São Paulo. São Paulo, SP, Brazil. ${ }^{4}$ Biologist at Instituto do Coração do Hospital das Clínicas da Faculdade de Medicina da Universidade de São Paulo. São Paulo, SP, Brazil. ${ }^{5}$ Doctor. Biologist at Instituto do Coração do Hospital das Clínicas da Faculdade de Medicina da Universidade de São Paulo. São Paulo, SP, Brazil. ${ }^{6}$ Full Professor. Physician at Instituto do Coração do Hospital das Clínicas da Faculdade de Medicina da Universidade de São Paulo. São Paulo, SP, Brazil.
}

Full Professor. Physician at Instituto do Coração do Hospital das Clínicas da Faculdade de Medicina da Universidade de São Paulo. São Paulo, SP, Brazil

${ }^{8}$ Full Professor. Physician at Instituto do Coração do Hospital das Clínicas da Faculdade de Medicina da Universidade de São Paulo. São Paulo, SP, Brazil.

${ }^{9}$ Full Professor. Physician at Instituto do Coração do Hospital das Clínicas da Faculdade de Medicina da Universidade de São Paulo. São Paulo, SP, Brazil

Correspondence to: Pedro Alves Lemos Neto. Av. Dr. Enéas Carvalho de Aguiar, 44 - Cerqueira César - São Paulo, SP, Brazil - CEP 05403-900 E-mail: pedro.lemos@incor.usp.br

Received on: 8/31/2012 • Accepted on: 11/26/2012 
gradable polymers at 28 days is not a definitive neointima. The most significant experimental evidence is the change in the neointimal characteristics observed at sequential OCT.

DESCRIPTORS: Tomography, optical coherence. Drug-eluting stents. Angioplasty. Polymers. Neointima.

C urrent knowledge of the vascular response and the resulting neointimal hyperplasia related to the implantation of drug-eluting stents (DES) is largely based on preclinical studies in porcine coronary arteries. ${ }^{1-4}$ In animals, peak neointimal growth with bare-metal stents (BMS) occurs at 28 days; with DES, studies in animals have shown favourable results for re-endothelialization at 28 days, albeit incomplete. . $^{5-8}$

Vascular healing in response to DES implantation is dynamic and depends on the type of drug used, which in turn depends on its release kinetics from durable or biodegradable polymers. ${ }^{9-16}$ Evaluation through histology does not allow for time-dependent analyses, and there are additional limitations, such as tissue loss related to the technique employed for material preparation (non-satisfactory cutting or colouring, thickness, and angle of the cut).

Due to its high resolution, optical coherence tomography (OCT) may be a promising intravascular imaging tool in the sequential evaluation of neointimal formation. Compared to histology, OCT allows for the evaluation of the vascular healing process in vivo at different stages, providing qualitative and quantitative information along the full length of the stent. ${ }^{17-20}$ By enabling analysis at multiple time points, it is possible to compare the same intrastent region at different times and thereby assess temporal neointima maturation, as well as to evaluate each intrastent millimetre strut by strut.

Based on the hypothesis that the neointima found in DES with biodegradable polymers at 28 days are not definitive, and that OCT is an effective method for the sequential evaluation of neointima, this experimental study aimed to compare the qualitative findings of OCT at 28 days and 90 days in two types of DES with biodegradable polymers: the sirolimus-eluting stent (Inspiron ${ }^{\circledR}$, Scitech Medical Products Ltda. - Goiânia, Brazil) and the biolimus-A9 eluting stent (Biomatrix ${ }^{\oplus}$, Biosensors International - Singapore).
$0 \%$ aos 90 dias, presença de tecido intraluminal em $18 \%$ aos 28 dias e em $0 \%$ aos 90 dias, irregularidade luminal em $62 \%$ aos 28 dias e em $2 \%$ aos 90 dias $(P<0,005)$. Não houve diferença entre os grupos quanto à qualidade da neoíntima ao longo do tempo $(P>0,05)$. Conclusões: Os achados à TCO corroboram a hipótese de que a neoíntima encontrada em SFs com polímeros biodegradáveis aos 28 dias não é a neoíntima definitiva. A evidência experimental mais significativa é a mudança das características da neoíntima observada à TCO sequencial

DESCRITORES: Tomografia de coerência óptica. Stents farmacológicos. Angioplastia. Polímeros. Neoíntima.

\section{METHODS}

All procedures followed the standards for laboratory animal protection and care established by the Ethical Principles in Animal Experimentation of the Research Support and Animal Experimentation Service of the Instituto do Coração da Faculdade de Medicina da Universidade de São Paulo, as well as the Guide for the Care and Use of Laboratory Animals (Institute of Laboratory Animal Resources, Commission on Life Sciences and National Research Council, National Academy Press, Washington, DC, 1996) and the Ethical Principles in Animal Experimentation of the Brazilian College of Animal Experimentation (COBEA).

\section{Subjects and stent implantation}

Six domestic juvenile, non-atherosclerotic pigs, weighing between $18 \mathrm{~kg}$ and $23 \mathrm{~kg}$, were obtained from a commercial breeding farm.

One day before the procedure, the pigs received $600 \mathrm{mg}$ of acetylsalicylic acid and $150 \mathrm{mg}$ of clopidogrel orally. The anaesthesia protocol consisted of premedication (ketamine $3 \mathrm{mg} / \mathrm{kg}$ and midazolam 0.5 $\mathrm{mg} / \mathrm{kg}$, intramuscular) followed by intravenous infusion of thiopental, endotracheal intubation, and the start of mechanical ventilation; the level of anaesthesia was maintained with isoflurane.

A $6 \mathrm{~F}$ vascular sheath was introduced under direct vision after dissection of the common femoral artery. A dose of 10,000 IU unfractionated heparin was administered and the left coronary artery was selectively catheterised under fluoroscopy using a Judkins right $(J R)^{4} 6 \mathrm{~F}$ guide catheter. Then, nitroglycerin was injected through the catheter at a dose of $200 \mu \mathrm{g}$, and an Inspiron $^{\circledast}$ or Biomatrix ${ }^{\circledR}$ stent was randomly implanted in each anterior descending or circumflex artery of each pig, trying to maintain a stent-releasing balloon/artery ratio of $1.1 / 1$. The Inspiron ${ }^{\circledR}$ stents were $2.5 \mathrm{~mm}$ or 3 $\mathrm{mm}$ in diameter and $16 \mathrm{~mm}$ in length. All implanted Biomatrix $^{\circledR}$ stents were $3 \mathrm{~mm}$ in diameter and $14 \mathrm{~mm}$ in length. 


\section{Optical coherence tomography}

An M2 OCT Imaging System (Imaging LightLab, Inc., Westford, USA) was used with ImageWire ${ }^{\circledR}$ automated catheter pullback (LightLab Imaging, Inc.) at a speed of $1 \mathrm{~mm} / \mathrm{s}$ and $2 \mathrm{~mm} / \mathrm{s}$ after proximal occlusion of the arterial segment under study with a Helios ${ }^{\circledR}$ balloon (LightLab Imaging, Inc.). Specific software from the OCT equipment was used to make measurements at 1 $\mathrm{mm}$ intervals starting from the most distal part of the stent and moving towards the proximal end.

\section{Morphometric Analysis}

The first stent image analysed was the one that allowed for the drawing of a complete circle using struts in the distal border. The stent and luminal areas were measured by manual tracing $\left(\mathrm{mm}^{2}\right)$. The neointimal area $\left(\mathrm{mm}^{2}\right)$ was calculated as the lumen area minus the stent area. The neointimal area percentage (\%) was calculated as the ratio between the neointimal area and the stent area (neointimal area percentage $=$ area of the stent - lumen area/stent area). For the analysis of neointimal thickness $(\mathrm{mm})$, the distance from the luminal surface of the stent strut reflection (called the "blooming artifact") to the luminal contour was measured. Since the blooming artefact was systematically included in the measurements, to determine strut apposition it was necessary to take into account its total thickness (thickness of the metal strut + thickness of the polymer + drug) plus a correction factor of $20 \mu \mathrm{m}$, which corrects for the actual location of the strut surface by discounting half of the blooming. ${ }^{18,19}$ The distance between the luminal surface of blooming produced by the struts and the contour of the vascular lumen was analysed individually for each strut. For the stents in this study, if the distance was greater than the sum of the thicknesses of the struts (Biomatrix ${ }^{\circledR}, 112 \mu \mathrm{m}$; Inspiron ${ }^{\circledR}, 75 \mu \mathrm{m}$ ) plus the thicknesses of the polymers (Biomatrix ${ }^{\circledR}, 10 \mu \mathrm{m}$; Inspiron ${ }^{\circledR}, 5 \mu \mathrm{m}$ ) plus $20 \mu \mathrm{m}$ (correction factor), the strut would be considered malpositioned.

\section{Characterisation of neointimal tissue}

The qualitative analysis evaluated transverse sections at each millimetre along the stent at 28 and 90 days. Features such as the presence of neointima with luminal irregularities, the presence of intraluminal tissue, and the heterogeneous aspects of neointima were detected and described.

Neointimal tissue with irregularities was defined by the presence of indistinct and irregular contours on the luminal surface of the vessel and by the presence or absence of discontinuous neointima. Intraluminal tissue was identified as material protruding into the vessel lumen, which may or may not adhere to the neointima. Heterogeneous aspects of neointimal tissue were identified when an image with low light intensity was observed in the OCT of neointimal tissue without signal attenuation behind the area (Figure 1).

These events were compared in cross-sectional OCT images taken after 28 and 90 days and evaluated regarding their progression or resolution.

\section{Statistical Analysis}

Data are shown as the mean \pm SD or as numbers and percentages. The comparison between days 28 and 90 , as well as the interaction of the effects of the type of stent and the progression/regression of the temporal neointima over time were analysed with a general linear model with repeated measures. The significance level was set at 5\%. Analyses were performed using SPSS 20.0 (IBM SPSS - Chicago, USA).

\section{RESULTS}

All six pigs survived the index procedure and underwent angiographic analysis and OCT at 28 days and at 90 days after implantation.

In total, 2,685 stent struts along $350 \mathrm{~mm}$ of total stent length were analysed (1,366 struts at 28 days and 1,319 struts at 90 days); 338 paired transverse sections were analysed at 28 days and at 90 days (Inspiron ${ }^{\circledR}=$ 90 and Biomatrix ${ }^{\circledR}=79$ transverse sections analysed at each time point) (Figure 2). Twelve transverse sections were excluded from the analysis due to image artifacts. No malpositioned struts were observed, as all struts analysed were covered by neointimal tissue.

Events such as the presence of luminal irregularities, heterogeneous aspects of neointimal tissue, and the presence of intraluminal tissue were evaluated in the 12 stents at 28 days. The presence of heterogeneous neointimal tissue, irregular lumen, and luminal tissue in the transverse sections was higher at 28 days than at 90 days $(38.8 \pm 28.2 \%$ vs. $0 \% ; \mathrm{P}=0.001 ; 62.4 \pm$ $23.1 \%$ vs. $2.2 \pm 5.1 \%$; $P<0.001 ; 17.9 \pm 16.3 \%$ vs. $0 \%$; $\mathrm{P}=0.005$, respectively). This behaviour was observed for both stents analysed (Table 1).

The incidence of qualitative events in the transverse sections analysed was similar at 28 days for both stents, and each showed heterogeneous neointimal tissue $(44.4 \% \pm 31.1$ and $33.2 \pm 26.6 \%$ for the Inspiron ${ }^{\circledR}$ and Biomatrix ${ }^{\circledR}$ stents, respectively; $\mathrm{P}=0.5$ ), intraluminal tissue $(18.1 \pm 20.7 \%$ and $17.7 \pm 12.5 \%$ for Inspiron ${ }^{\circledR}$ and Biomatrix ${ }^{\circledR}$ stents, respectively; $\mathrm{P}>0.9$ ) and luminal irregularities $(67.9 \pm 20 \%$ and $56.9 \pm$ $26.4 \%$ for Biomatrix ${ }^{\circledR}$ and Inspiron ${ }^{\circledR}$ stents, respectively; $\mathrm{P}=0.5$ ) (Table 1). 


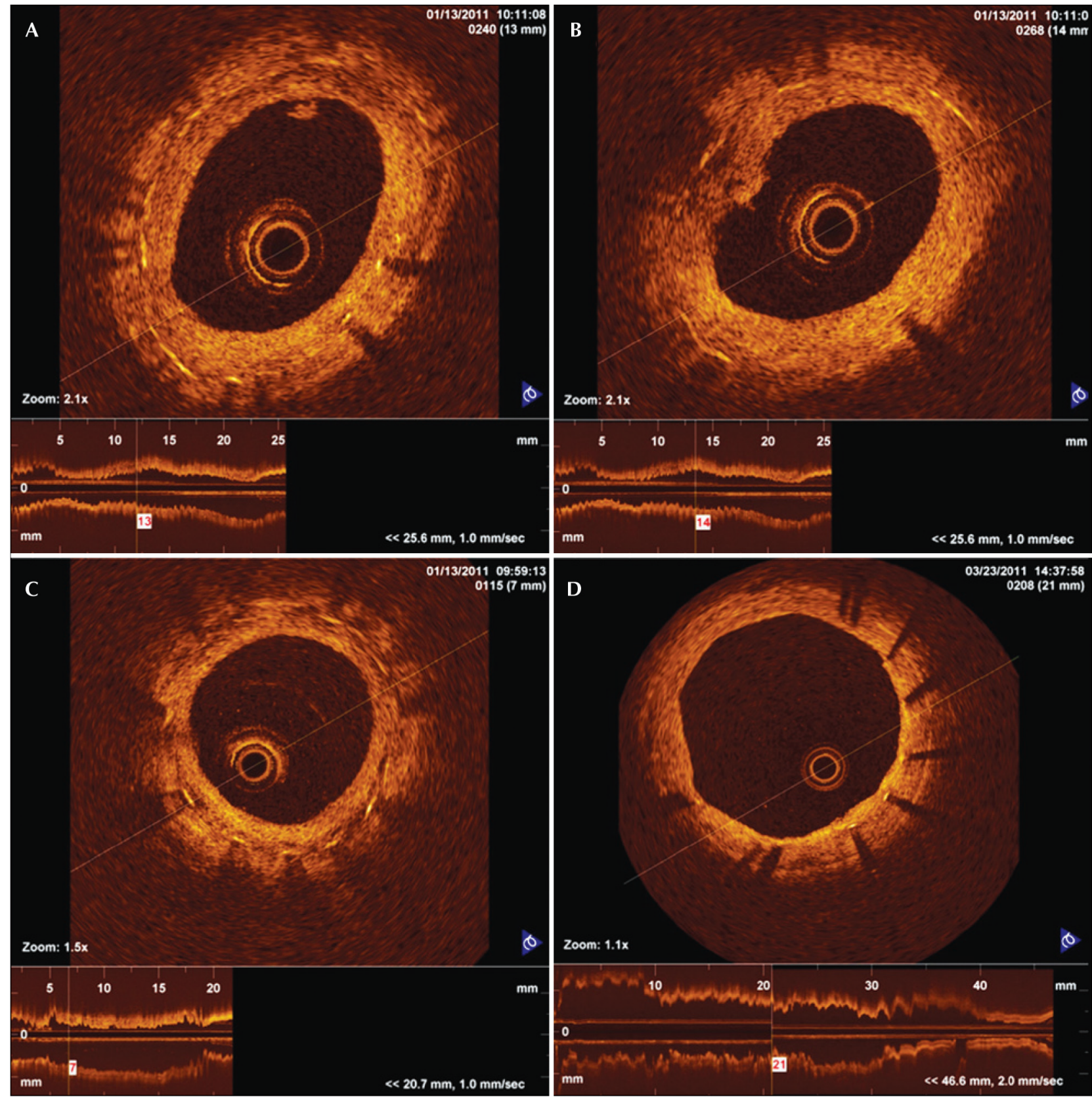

Figure 1 - Optical coherence tomography images of a cross-section of porcine coronaries with DES. In A, intraluminal tissue, which is material that is located in the vessel lumen and may or may not adhere to the neointimal tissue. In B, neointimal tissue with irregularities, showing the presence of irregular and indistinct borders of the luminal surface of the vessel with the presence or absence of discontinuous neointima. In C, heterogeneous aspects of neointimal tissue are depicted in the image showing low light intensity of neointimal tissue near the stent struts. In $\mathbf{D}$, homogeneous aspects of neointimal tissue with light intensity compatible with normal neointima are shown.

\section{DISCUSSION}

Several studies in animal models and previous clinical trials showed delayed endothelialisation of DES when compared to BMS, ${ }^{21-23}$ and observed the frequent presence of struts covered by thin layers of neointimal tissue, with a thickness well below the limits of detection by intracoronary ultrasound. This delayed endothelialisation may play an important role in the pathogenesis of DES thrombosis. ${ }^{23,24}$ Additionally, autopsy studies have identified the presence of bare struts as a more robust morphological predictor for the occurrence of thrombosis in first-generation DES. ${ }^{25}$

The present study with sequential OCT, despite not showing bare struts, did provide images that indicate 

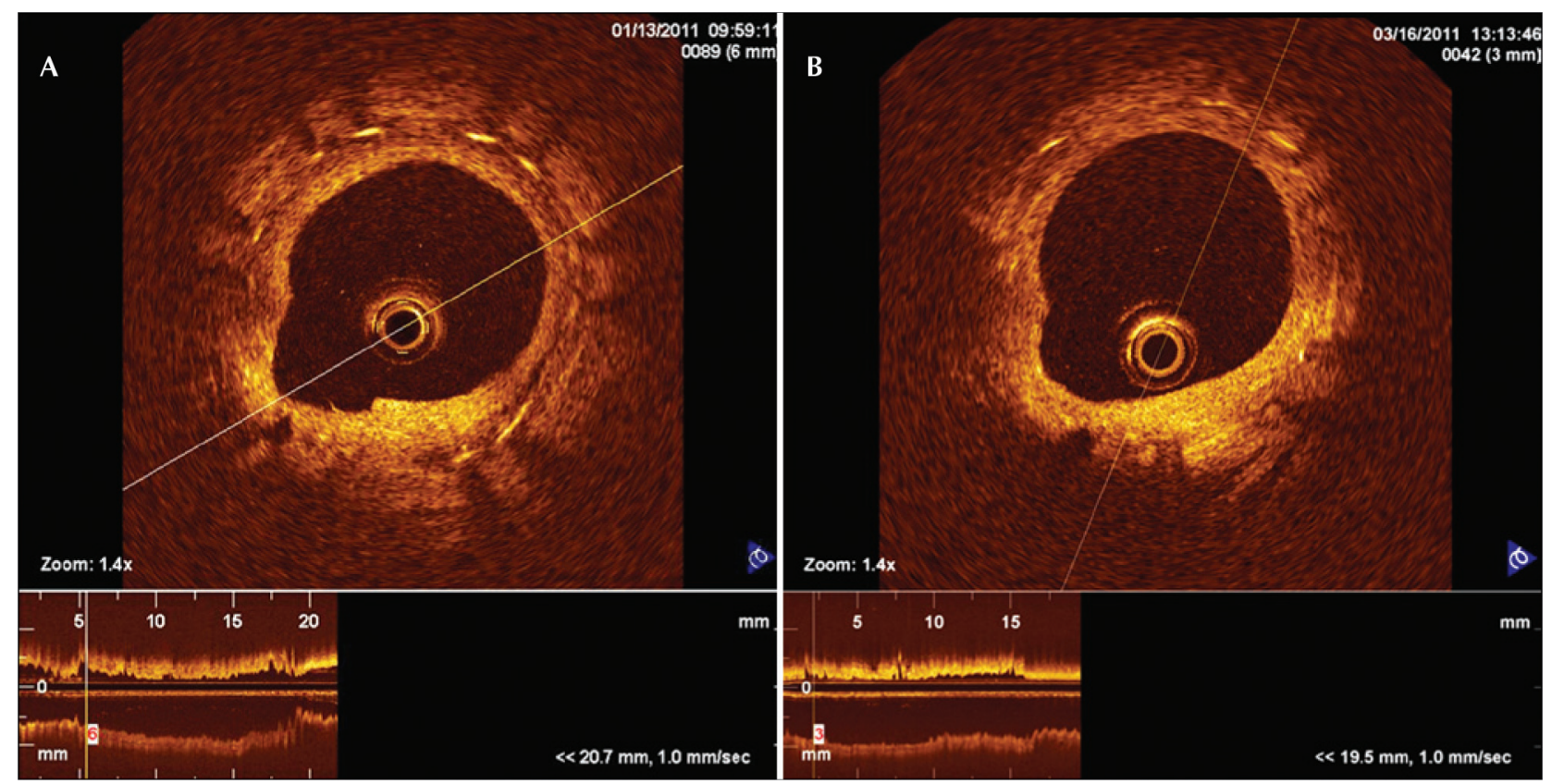

Figure 2 - Paired optical coherence tomography images of a cross-section of the Inspiron ${ }^{\oplus}$ stent implanted in the left anterior descending artery at 28 days (A) and 90 days (B). At 28 days, the heterogeneous aspects of the neointimal tissue can be observed, which are replaced by homogeneous aspects at 90 days.

Table 1

Quantitative and qualitative findings from sequential optical coherence tomography images taken at 28 and 90 days after Inspiron ${ }^{\circledR}$ and Biomatrix ${ }^{\circledR}$ stent implantation in porcine coronary arteries

\begin{tabular}{|c|c|c|c|c|c|c|c|c|}
\hline & \multicolumn{3}{|c|}{28 days } & \multicolumn{3}{|c|}{90 days } & \multirow{2}{*}{$\begin{array}{c}P \\
\text { (28 days } \\
\text { vs. } 90 \\
\text { days } \\
\end{array}$} & \multirow{2}{*}{$\begin{array}{c}\text { P } \\
\text { (Interaction } \\
\text { Inspiron }^{\circledR} \text { vs. } \\
\text { Biomatrix }^{\circledR} \text { ) }\end{array}$} \\
\hline & $\begin{array}{c}\text { Inspiron }^{\circledR} \\
(\mathbf{n}=90)\end{array}$ & $\begin{array}{c}\text { Biomatrix }^{\circledR} \\
(n=79)\end{array}$ & $\begin{array}{c}\text { Global } \\
(n=169)\end{array}$ & $\begin{array}{c}\text { Inspiron }^{\circledast} \\
(\mathbf{n}=90)\end{array}$ & $\begin{array}{c}\text { Biomatrix }^{\circledR} \\
\quad(n=79)\end{array}$ & $\begin{array}{c}\text { Global } \\
(n=169)\end{array}$ & & \\
\hline Luminal area, $\mathrm{mm}^{2}$ & $3.29 \pm 0.96$ & $3.94 \pm 0.46$ & $3.62 \pm 0.76$ & $3.24 \pm 0.94$ & $3.75 \pm 0.99$ & $3.50 \pm 0.96$ & 0.6 & 0.8 \\
\hline Stent area, $\mathrm{mm}^{2}$ & $5.32 \pm 0.78$ & $5.75 \pm 0.38$ & $5.53 \pm 0.62$ & $5.45 \pm 0.94$ & $5.85 \pm 0.57$ & $5.65 \pm 0.77$ & 0.5 & 0.9 \\
\hline $\begin{array}{l}\text { NIH percentage } \\
\text { load, \% }\end{array}$ & $39.2 \pm 11$ & $31.1 \pm 10.3$ & $35.2 \pm 11$ & $40.9 \pm 10$ & $35.3 \pm 17.6$ & $38.1 \pm 13.9$ & 0.4 & 0.8 \\
\hline $\mathrm{NIH}$ area, $\mathrm{mm}^{2}$ & $2.08 \pm 0.35$ & $1.80 \pm 0.71$ & $1.92 \pm 0.55$ & $2.21 \pm 0.58$ & $2.09 \pm 1.09$ & $2.15 \pm 0.84$ & 0.3 & 0.8 \\
\hline $\begin{array}{l}\mathrm{NIH} \text { thickness, } \\
\mathrm{mm}^{2}\end{array}$ & $0.27 \pm 0.06$ & $0.22 \pm 0.10$ & $0.24 \pm 0.09$ & $0.30 \pm 0.08$ & $0.29 \pm 0.15$ & $029 \pm 0.12$ & 0.1 & 0.5 \\
\hline $\begin{array}{l}\text { TS with } \\
\text { heterogeneous } \\
\text { NIH }\end{array}$ & $44.4 \pm 31.1$ & $33.2 \pm 26.6$ & $38.8 \pm 28.2$ & $0 \pm 0$ & $0 \pm 0$ & $0 \pm 0$ & 0.001 & 0.5 \\
\hline $\begin{array}{l}\text { TS with intimal } \\
\text { irregularity }\end{array}$ & $67.9 \pm 20$ & $56.9 \pm 26.4$ & $62.4 \pm 23.1$ & $2 \pm 4.8$ & $2.4 \pm 5.8$ & $2.2 \pm 5.1$ & $<0.001$ & 0.5 \\
\hline $\begin{array}{l}\text { TS with } \\
\text { intraluminal tissue }\end{array}$ & $18.1 \pm 20.7$ & $17.7 \pm 12.5$ & $17.9 \pm 16.3$ & $0 \pm 0$ & $0 \pm 0$ & $0 \pm 0$ & 0.005 & $>0.9$ \\
\hline
\end{tabular}


heterogeneity in the healing process after 28 days. This result suggests that this is a step in the neointimal tissue maturation process for both stents studied, since, at 90 days, no heterogeneous neointimal tissue, luminal irregularity, and intraluminal tissue were observed.

It should be noted that at both 28 and 90 days, although the process of stent endothelialisation is faster in pigs than in humans, ${ }^{7}$ polymers from both Inspiron ${ }^{\circledR}$ and Biomatrix ${ }^{\circledR}$ stents are still present and undergoing degradation and their respective antiproliferative drugs are still present. ${ }^{12,26} \mathrm{~A}$ study with a later evaluation time point ( $>$ six months) may be needed to analyse DES in order to evaluate the inflammatory and chronic biological responses after drug elution and polymer degradation.

It will be important to correlate the OCT findings with histological data to identify and understand the neointima maturation process. Teramoto et al. ${ }^{27}$ correlated images with low light intensity signal visualised in OCT with histological findings, and observed areas of low cellularity and the presence of fibrin and proteoglycans.

Second-generation OCT systems, which are already available for both pre-clinical and clinical use (Fourierdomain optical coherence tomography [FDOCT]), are capable of acquiring images at higher speeds with fewer artefacts and without the need for proximal occlusion of the coronary artery. Recent FDOCT studies compared the optical density of neointimal tissue longitudinally after stent implantation to differentiate fibrin from neointimal tissue. ${ }^{28,29}$

These findings corroborate the results of the present study, as they demonstrated neointimal maturation over time and showed a progressive reduction in the amount of fibrin and its replacement by neointimal tissue, which was maintained after 28 days.

Further evaluations are needed to better understand the possible roles of these different regions in neointimal tissue in the arterial healing process after implantation of DES.

\section{Study limitations}

Qualitative analyses were performed by a single investigator; therefore, the assessment of the qualitative characteristics of the neointima could be biased despite the best efforts to remain objective.

The DES were implanted in porcine non-atherosclerotic coronary arteries and the vascular response was evaluated in the context of normal porcine coronary arteries. Preclinical studies with these stents in the arteries of animals with experimental atherosclerosis (minipigs, rabbits) can mora accurately answer the questions regarding the effectiveness of these stents. ${ }^{21}$

\section{CONCLUSIONS}

The OCT results corroborate the hypothesis that the neointima found in DES with biodegradable polymers at 28 days is not the definitive neointima. The most significant experimental evidence is the change in characteristics of the neointima observed in OCT images taken after 90 days. This fundamental tool is useful in the preclinical analysis of stents, allowing the sequential assessment of neointimal tissue in vivo.

\section{FINANCIAL SUPPORT}

The present study is part of the National Development Program of Vascular Stents (PDNS), initiated in 2004-2005. It is supported by the Secretariat of Science, Technology and Strategic Inputs (SCTIE)/Department of Science and Technology (DECIT), the Brazilian Ministry of Health, the National Council for Scientific and Technological Development (CNPq) and the Financier of Studies and Projects (FINEP) of the Brazilian Ministry of Science and Technology. The development of the laser cutting of stents was supported by the Foundation for Research Support of the State of São Paulo (FAPESP; Support type: Technological Innovation/Innovative Research in Small and Micro Enterprises [PIPE]).

\section{CONFLICT OF INTEREST}

Celso K. Takimura and Francisco R. M. Laurindo are scientific consultants at Scitech Medical Products. Over the past 36 months, Pedro A. Lemos has been a scientific consultant to Scitech Medical Products and has delivered national and international lectures sponsored by Boston Scientific and Braun; he is also a member of Boston Scientific Latin America SCIMAB (Scientific Medical Advisory Board). The remaining authors declare to have no conflicts of interest.

\section{REFERENCES}

1. Suzuki Y, Yeung AC, Ikeno F. Importância dos estudos préclínicos em animais de experimentação para a cardiologia intervencionista. Arq Bras Cardiol. 2008;91(5):348-60.

2. Schwartz RS, Huber KC, Murphy JG, Edwards WD, Camrud AR, Vliestra RE, et al. Restenosis and the proportional neointimal response to coronary artery injury: results in a porcine model. J Am Coll Cardiol. 1992;19(2):267-74.

3. Schwartz RS, Holder DJ, Holmes DR, Veinot JP, Camrud AR, Jorgenson MA, et al. Neointimal thickening after severe coronary artery injury is limited by a short-term administration of a factor Xa inhibitor: results in a porcine model. Circulation. 1996;93(8):1542-8

4. Ikeno F, Buchbinder M, Yeung AC. Novel stent and delivery systems for the treatment of bifurcation lesions: porcine coronary artery model. Cardiovasc Revasc Med. 2007;8(1):38-42.

5. Carter AJ, Laird JR, Farb A, Kufs W, Wortham DC, Virmani R. Morphologic characteristics of lesion formation and time course of smooth muscle cell proliferation in a porcine proliferative restenosis model. J Am Coll Cardiol. 1994;24(5):1398-405.

6. Edelman ER, Rogers C. Pathobiologic responses to stenting. Am J Cardiol. 1998;81(7A):4E-6E.

7. Virmani R, Kolodgie FD, Farb A, Lafont A. Drug eluting stents: are human and animal studies comparable?. Heart. 2003;89(2):133-8. 
8. Kotani J, Awata M, Nanto S, Uematsu M, Oshima F, Minamiguchi $\mathrm{H}$, et al. Incomplete neointimal coverage of sirolimus-eluting stents: angioscopic findings. J Am Coll Cardiol. 2006;47(10):2108-11.

9. Nakazawa G, Finn AV, John MC, Kolodgie FD, Virmani R. The significance of preclinical evaluation of sirolimus-, paclitaxel-, and zotarolimus-eluting stents. Am J Cardiol. 2007; 100(8B):36M-44M.

10. Stone GW, Ellis SG, Cox DA, Hermiller J, O'Shaughnessy C, Mann JT, et al. One-year clinical results with slow-release, polymer-based, paclitaxel-eluting TAXUS stent: the TAXUS-IV trial. Circulation. 2004;109(16):1942-7.

11. Joner M, Finn AV, Farb A, Mont EK, Kolodgie FD, Ladich E, et al. Pathology of drug-eluting stents in humans: delayed healing and late thrombotic risk. J Am Coll Cardiol. 2006;48(1): 193-202.

12. Byrne RA, Mehilli J, lijima R, Schulz S, Pache J, Seyfarth M, et al. A polymer-free dual drug-eluting stent in patients with coronary artery disease: a randomized trial vs. polymer-based drug-eluting stents. Eur Heart J. 2009;30(8):923-31.

13. Chamié D, Costa Jr. JR, Abizaid A, Silva JFA, Feres F, Mattos LM, et al. Stents liberadores de sirolimus com e sem cobertura polimérica: análise seriada com angiografia e ultrassom intracoronariano tridimensional. Rev Bras Cardiol Invasiva. 2009; $17(1): 20-30$.

14. Windecker S, Serruys PW, Wandel S, Buszman P, Trznadel S, Linke $A$, et al. Biolimus-eluting stent with biodegradable polymer versus sirolimus-eluting stent with durable polymer for coronary revascularization (LEADERS): a randomized noninferiority trial. Lancet. 2008;372(9644):1163-73.

15. Takimura CK, Watanabe IS, Campos CAHM, Laurindo FRM, Ferreira CN, Gutierrez PS, et al. Avaliação por microscopia eletrônica de varredura da endotelização pós implante de stent farmacológico Scitech em artérias ilíacas de coelhos. Rev Bras Cardiol Invasiva. 2010;18 Supl 2:27.

16. Takimura CK, Galon MZ, Lopes Jr. ACA, Carvalho J, Ferreira SK, Chaves MJF, et al. Avaliação pela tomografia de coerência óptica de stent nacional recoberto com polímero biodegradável eluidor de sirolimus vs. stent eluidor de biolimus A9 em artérias coronárias porcinas. Rev Bras Cardiol Invasiva. 2011;19(2):138-44.

17. Guagliumi G, Musumeci G, Sirbu V, Bezerra HG, Suzuki N, Fiocca $\mathrm{L}$, et al. Optical coherence tomography assessment of in vivo vascular response after implantation of overlapping bare-metal and drug-eluting stents. JACC Cardiovasc Interv. 2010;3(5):531-9.

18. Mehanna EA, Attizzani GF, Kyono H, Hake M, Bezerra HG. Assessment of coronary stent by optical coherence tomography, methodology and definitions. Int J Cardiovasc Imaging. 2011;27(2):259-69.

19. Bezerra HG, Costa MA, Guagliumi G, Rollins AM, Simon DI. Intracoronary optical coherence tomography: a comprehensive review clinical and research applications. JACC Cardiovasc Interv. 2009;2(11):1035-46.

20. Tahara S, Chamie D, Baibars M, Alraies C, Costa M. Optical coherence tomography endpoints in stent clinical investigations: strut coverage. Int J Cardiovasc Imaging. 2011;27(2):271-87.

21. van Beusekom HM, Saia F, Zindler JD, Lemos PA, Swager-Ten Hoor SL, van Leeuwen MA, et al. Drug-eluting stents show delayed healing: paclitaxel more pronounced than sirolimus. Eur Heart J. 2007;28(8):974-9.

22. Lim SY, Jeong MH, Hong SJ, Lim do S, Moon JY, Hong YJ, et al. Inflammation and delayed endothelization with overlapping drug-eluting stents in a porcine model of in-stent restenosis. Circ J. 2008;72(3):463-8.

23. Finn AV, Joner M, Nakazawa G, Kolodgie F, Newell J, John MC, et al. Pathological correlates of late drug-eluting stent thrombosis: strut coverage as a marker of endothelialization. Circulation. 2007;115(18):2435-41

24. Nakazawa G, Finn AV, Joner M, Ladich E, Kutys R, Mont EK, et al. Delayed arterial healing and increased late stent thrombosis at culprit sites after drug-eluting stent placement for acute myocardial infarction patients: an autopsy study.Circulation. 2008;118(11):1138-45

25. Finn AV, Joner M, Nakazawa G, Kolodgie F, Newell J, John MC, et al. Pathological correlates of late drug-eluting stent thrombosis: strut coverage as a marker of endothelialization. Circulation. 2007;115(18):2435-41

26. Ribeiro EE. Estudo randomizado INSPIRON I: dois anos de follow-up. In: XXXIV Congresso da Sociedade Brasileira de Hemodinâmica e Cardiologia Intervencionista; 2012 jun. 2022; Salvador, BA, Brasil.

27. Teramoto $\mathrm{T}$, Ikeno $\mathrm{F}$, Otake $\mathrm{H}$, Lyons JK, van Beusekom HM, Fearon WF, et al. Intriguing peri-strut low-intensity area detected by optical coherence tomography after coronary stent deployment. Circ J. 2010;74(6):1257-9

28. Templin C, Meyer M, Müller MF, Djonov V, Hlushchuk R. Coronary optical frequency domain imaging (OFDI) for in vivo evaluation of stent healing: comparison with light and electron microscopy. Eur Heart J. 2010;31(14):1792-801.

29. Attizzani GF, Bezerra HG, Chamié D, Fujino Y, Spognardi AM, Stanley JR, et al. Serial Evaluation of Vascular Response After Implantation of a New Sirolimus-Eluting Stent With Bioabsorbable Polymer (MISTENT): an optical coherence tomography and histopathological study. J Invasive Cardiol. 2012;24(11):560-8. 